Vol. 38(1), pp. 27-46, June 2019

ISSN 1821-536X (print)

ISSN 2619-8789 (electronic)
Tanzania Journal of Engineering and Technology

Copyright $\odot 2019$ College of Engineering and

Technology, University of Dar es Salaam

Full Length Research Paper

\title{
Assessment of surface water resources in Great Ruaha River sub-basin Tanzania: Application of WEAP model for water allocation and utilization impacts analysis
}

\author{
Rose Gervas, Deogratias M.M. Mulungu* and Joel K. Nobert
}

Department of Water Resources Engineering, College of Engineering and Technology, University of Dar es Salaam, P.O. Box 35131, Dar es Salaam, Tanzania.

*Corresponding author: dmulungu@udsm.ac.tz; deorgm@yahoo.co.uk

\begin{abstract}
The Great Ruaha River (GRR) sub-basin is one of the most important waterways in Tanzania as it supports important economic activities. The sub-basin is progressively faced with an inevitable situation of increasing water demand among competing users while the quantity and quality of water is diminishing. The focus of this study was to assess allocation of existing (2012) and future (up to 2025) quantities of surface water in the GRR sub-basin with consideration of priorities given in the Tanzania Water Resources Management Act, 2009 in the order: domestic, environment, agriculture, livestock and non-domestic. Simulation of water allocation scenarios of irrigation expansion (IE) and implementation of environmental flow requirements (EWD) and their impacts on met demands was done by using WEAP model. Results showed that under current and future conditions, available streamflows are sufficient for the first two water use priorities. Implementation of EWD and IE scenarios will change demands in comparison with reference scenario by $80 \%,-38 \%$ and $45 \%$ and shortages by 147\%, 123\% and 13\% in Little Ruaha, Ndembera and Kisigo catchments respectively. To eliminate water shortages, construction of reservoirs, use of alternative supply sources (especially in agriculture) and water demand management measures are recommended.
\end{abstract}

Keywords: Great Ruaha River, Rufiji basin, scenarios, water allocation, water shortage, WEAP model.

INTRODUCTION

\section{Background Information}

Recently it is commonly recognized that the basic human needs such as food, shelter and well-being are being affected by human activities on the environment. Climate change and increasing use of river water resources have resulted into significant changes in river flow regimes. As a result, aquatic life and ecology have mainly been affected. Water is an important aspect of development, livelihood and ecosystems. However, there are water management challenges due to growing water demands (Kashaigili et al., 2005).

The Great Ruaha River (GRR) is a major and important tributary in the Rufiji Basin, Tanzania. It contributes to water flow for hydropower production, irrigation and livelihood to the rural areas. Hydropower production in the river accounts for $50 \%$ of the Tanzania's installed capacity (Kadigi et 
al., 2004). The river is also important for ecology of the Usangu wetlands and the Ruaha National Park (RNP) (Kashaigili et al., 2005; Kashaigili et al., 2006).

There is great interest on the GRR for agricultural development, but previous experience indicated severe water shortage at Mtera reservoir resulting into power shortages and rationing in the country. Also, there were experienced low to dry flows since 1993 in GRR, which is the major source of water for the RNP that is covering $30 \%$ of basin area (SMUWC, 2001). As a result, wildlife and aquatic life is impaired leading to threats to tourism attractions, irrigation water supply and livestock grazing areas. This dryness has had implications on the water allocated to livelihood of the people, the economy and significant biodiversity in the Ruaha catchment area (Kashaigili et al., 2005). Surface water is preferable than groundwater for domestic and agricultural utilization due to challenges in obtaining groundwater potential data (Lankford, 2002). The total irrigated area located in the upland areas of the basin varies from 20,000 to 40,000 ha as a function of annual rainfall. This area includes largescale, state-owned farms, traditional smallholder; improved smallholder, and smallholder peripheral to the state farm.

Increasing economic activity, especially in irrigated agriculture (notably maize and rice) and in the production of energy, is placing huge pressure on the water resources of the catchment. Over allocation and heavy abstraction of water has resulted in dramatically reduced instream flows. There is increase in upstream diversions and consequent reduced inflows to the Usangu plains that resulted into conflicts between upstream and downstream communities. Mwakalila (2005) found out that, the main causes of water conflicts are: insufficient water (40\%), unequal water distribution $(30 \%)$ and water mismanagement $(30 \%)$. Further there is no proper mechanism for monitoring of water permits which have been issued so as to know if the abstractions are according to the given permits. There is also increase in illegal water abstractions for different activities specifically irrigation. Furthermore, there are noticeable river flow reductions in the central Usangu Plains, Ruaha National Park, and to the Mtera and Kidatu reservoirs due to increase in expansion of irrigated land. Despite all these challenges, there is no any current scientific information on water availability and analysis of water allocation for different users according to their demand and water availability for future expansions.

Chanzi (2017) performed water allocation using WEAP in Kilombero sub-basin of the Rufiji basin and Munkyala (2017) analyzed water allocation scenarios using the Nile Basin Decision Support System in Ndembera sub-basin of the GRR. While Kilombero sub-basin is outside the GRR basin and Ndembera just a portion of the GRR basin, there is a need to have a dedicated study for the entire GRR subbasin following its importance in the Rufiji River basin. Due to this, decision makers need to be informed on the available resource, meeting the demands and tools or mechanisms for water allocations in the GRR sub-basin. Variable and changing climatic conditions, notably in the form of increasing temperatures, associated with increases in evaporation and transpiration, are affecting both the supply of, and demand for, water and energy. Also, population growth is driving an increasing demand for agricultural land, clearance of natural vegetation and poor land management practices, leading to soil erosion and the degradation of water sources, increased water abstraction and competition for water resources.

For that matter, the study entails to assess the water resources allocation so as to improve water resources use and 
management in the GRR sub-basin, and develop alternative plausible future scenarios in order to assess impacts of different development options for water allocation. This was implemented integrally using computer based decision support software called Water Evaluation and Planning System (WEAP). Ultimately, the study is anticipated to contribute to sustainable management, development, allocation and utilization of the water resources in the GRR sub-basin by providing information critical to decision making.

\section{METHODS AND MATERIALS}

\section{Description of the Study Area}

The GRR sub-basin (Figure 1) is located in the southwest of Tanzania approximately latitudes $6^{0} 4^{\prime}$ and $9^{0} 41^{0}$ South, and longitudes $33^{\circ} 40^{\prime}$ and $37^{0} 41^{\prime}$ East (Kashaigili et al., 2005). The GRR subbasin has three main river catchments: Great Ruaha, Kisigo and Little Ruaha catchments (Figures $1 \& 3$ ). The lower part of GRR sub-basin includes the Mtera and Kidatu reservoirs. The Great Ruaha catchment and the lower part of GRR subbasin are part of the main river while Kisigo and Little Ruaha catchments form tributaries to the GRR River which flows to join Rufiji River downstream. The GRR is an important and main tributary of the Rufiji River draining an area of about $85,554 \mathrm{~km}^{2}$. It lies within the eastern arm of the Rift Valley, marked by distinct escarpments in the southern and eastern parts and forms the upper catchment of the GRR. The Rufiji River Basin (RRB) is the largest drainage basin in Tanzania, covering some $177,000 \mathrm{~km}^{2}$ or about $18 \%$ of the Tanzanian mainland. Located in the upper part of the Great Ruaha catchment are the Usangu plains with a total area of $20,811 \mathrm{~km}^{2}$, which is about $24 \%$ of the GRR sub-basin and $12 \%$ of the Rufiji Basin. There are many rivers draining into the plains while the major ones are Mbarali, Kimani, Chimala and Ndembera. The small rivers are: Umrobo, Mkoji, Lunwa, Mlomboji, Ipatagwa, Mambi and Mswiswi rivers. After these tributaries join the GRR, the river passes through a natural weir at Nyaluhanga and it supplies water to the Eastern wetland and the Ihefu swamp. The GRR is the major source of water as it flows through RNP to the Mtera reservoir. After confluence of GRR and Little Ruaha River, the river flows into Mtera reservoir. At Mtera, the power plant with $80 \mathrm{MW}$ installed capacity generates power for the national grid. The outflow from Mtera reservoir goes into Kidatu after confluence with Lukosi and Yovi Rivers supplying water for the $204 \mathrm{MW}$ installed capacity Kidatu power plant. The GRR then flows into Kilombero plains after confluence with Kilombero River and it forms a major tributary of Rufiji River (Kashaigili et al., 2005).

The GRR which in the past was perennial, since early 1990s has consistently ceased flowing in the dry season largely due to human diversions of water upstream of the Usangu wetlands (SMUWC, 2001; Lankford et al., 2004). Furthermore, since 1993, outflow from the Ihefu, the perennial swamp has ceased for prolonged periods during every dry season (Kashaigili et al., 2005). 


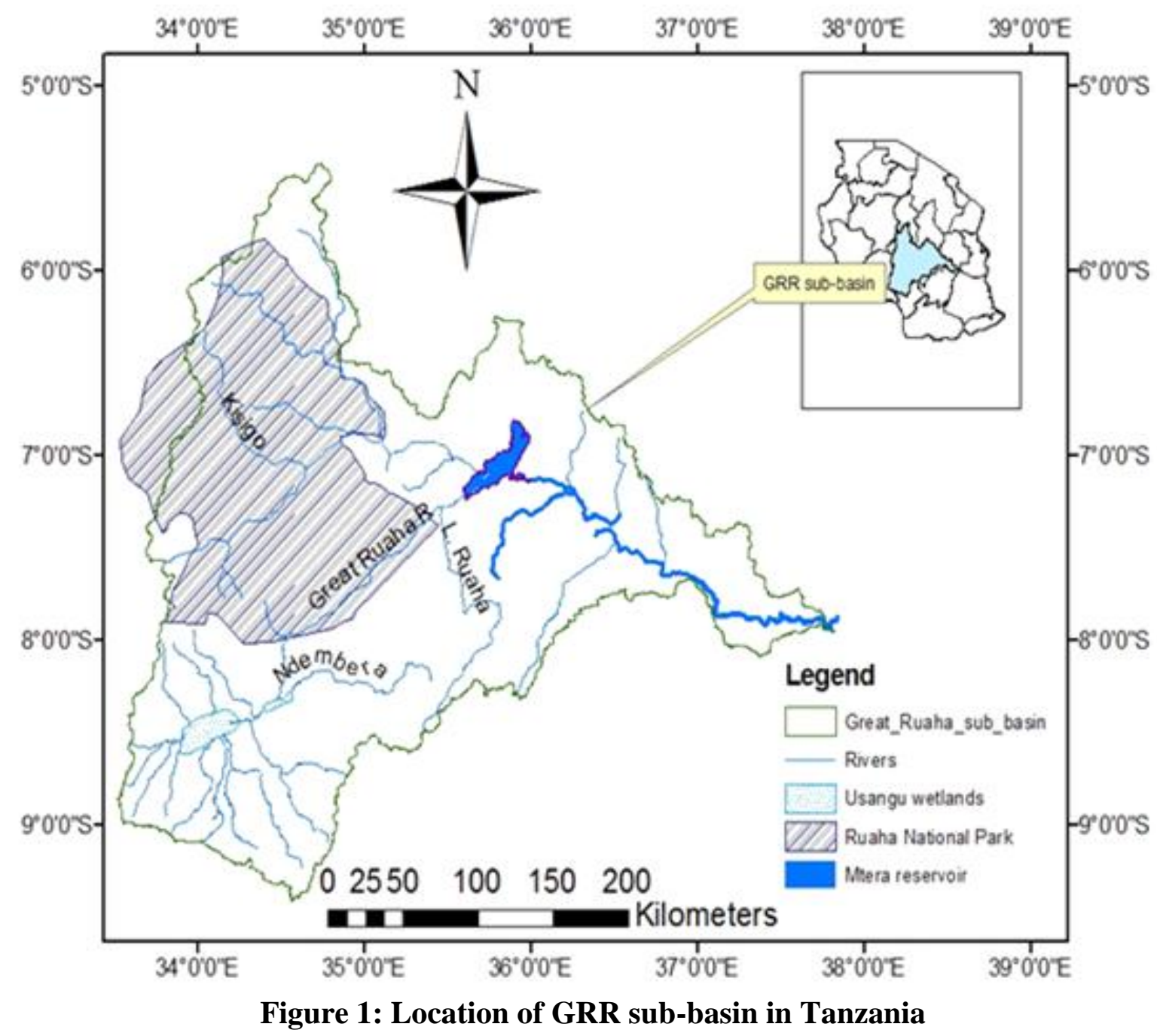

\section{Data and Methods}

To assess water allocation in GRR, Gervas (2013) estimated current and future water demands and water availability for development activities based on master plans in the Ministry of Agriculture, Food Security and Cooperatives (MAFC), and the Ministry of Water. Also, in order to perform water allocations for different uses, the WEAP model was calibrated and used for simulations of water use scenarios in the GRR sub-basin. The input data was checked for outliers and preprocessed to a suitable format before use for WEAP modeling.

\section{Assessment of water allocation scenarios} in the sub-basin

Kashaigili et al. (2005) found out that the need to achieve efficient allocation of water resources in Tanzania is becoming imperative, as water scarcity increases. The Tanzania Water Resources Management Act, 2009 gives water allocation priorities in the order: domestic, environment, agriculture, livestock and non-domestic. This was adhered in this study. Due to the fact that water resources management at the basin level involves different complexities, computer models were used to help allocation of available water resources among the different users. There are a number of water resources allocation models (e.g. WEAP, Stockholm Environmental Institute (SEI), Sieber et 
al., 2005); Mike Basin (DHI, 2006); REsource ALlocation Model (REALM), (Perera et al., 2005) and Aquarius), and the decision on which one to use depends on among other things, on the level of natural systems representation complexity desired, data availability, cost and details desired by the analyst. Water allocation and simulation of future water demand and supply using scenario in GRR sub-basin was done by WEAP model, which uses a water balance principle and runs on monthly basis (Figure 2). "The user represents the system in terms of its various sources of supply (e.g. rivers, groundwater, and reservoirs), withdrawals, water demands, and ecosystem requirements" (Sieber et al., 2002). WEAP model in this case was chosen as it is comprehensive, straightforward and easyto-use, and attempts to assist rather than substitute for the skilled planner. Data requirements and availability was also considered during selection of the model. WEAP can perform many functions at once since it uses a database that provides a system for maintaining and manipulation of water demand and supply information. One of the first water allocation studies in Tanzania was done by Mulungu and Taipe (2012) who successfully set up the WEAP model and performed water allocation in Wami River sub-basin. Other studies include that of Chanzi (2017) in Kilombero sub-basin of the RRB and Kishiwa et al. (2018) in Upper Pangani River sub-basin of the Pangani River Basin.

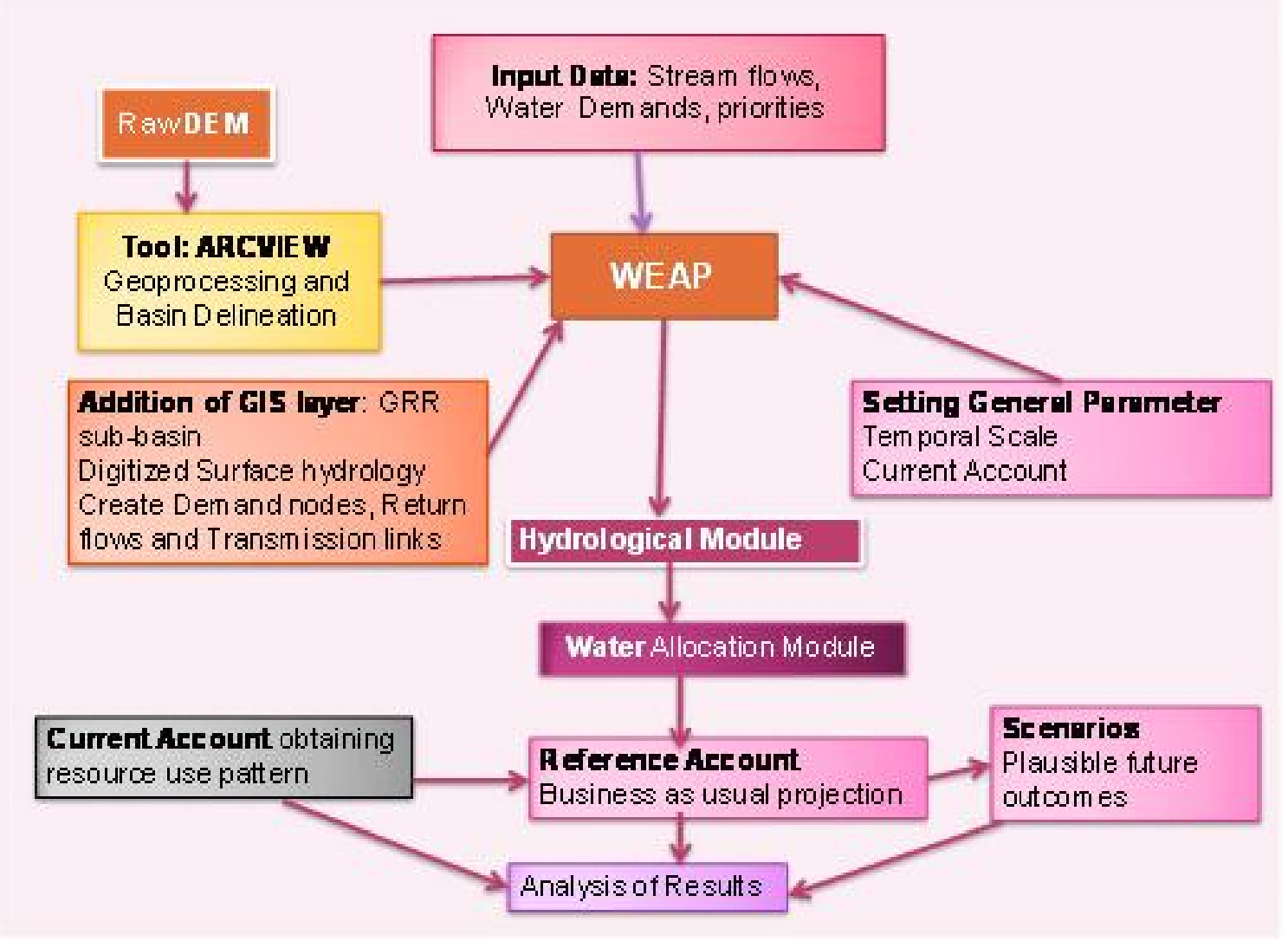

Figure 2: The conceptual structure of WEAP model (Source: Sieber et al., 2005)

WEAP application involves having a recent "baseline" year where water availability and demands are well known. Then the model is used in scenario mode which expresses or simulates the "what if" conditions of the different water development alternatives or options (Arranz and McCartney, 2007). When 

model for water allocation and utilization impacts analysis

water is limited, the algorithm is formulated to progressively restrict water allocation to those demand sites given the lowest priority (Sieber et al., 2005).

\section{Setting-up of the WEAP model in GRR sub-basin}

The study area is setup using the physical elements consisting of water demand and supply system at their spatial locations, timeframe for analysis, units of variables and hydrologic regimes. Accordingly, the study area was set and defined by geographical boundaries and specific water supply system (GRR sub-basin). The GRR sub-basin with an approximate area of $85,554 \mathrm{~km}^{2}$ was achieved by setting the boundary function of the model, selecting Tanzania from the global map in WEAP and adding an already delineated catchment with three catchments (Figure 3 ) into the program. The point of focus was the demand sites and the water supplies in GRR sub-basin. The study area in WEAP is represented by clearly outlined database for water supply and demand, which allows for storage, management and analysis of data.

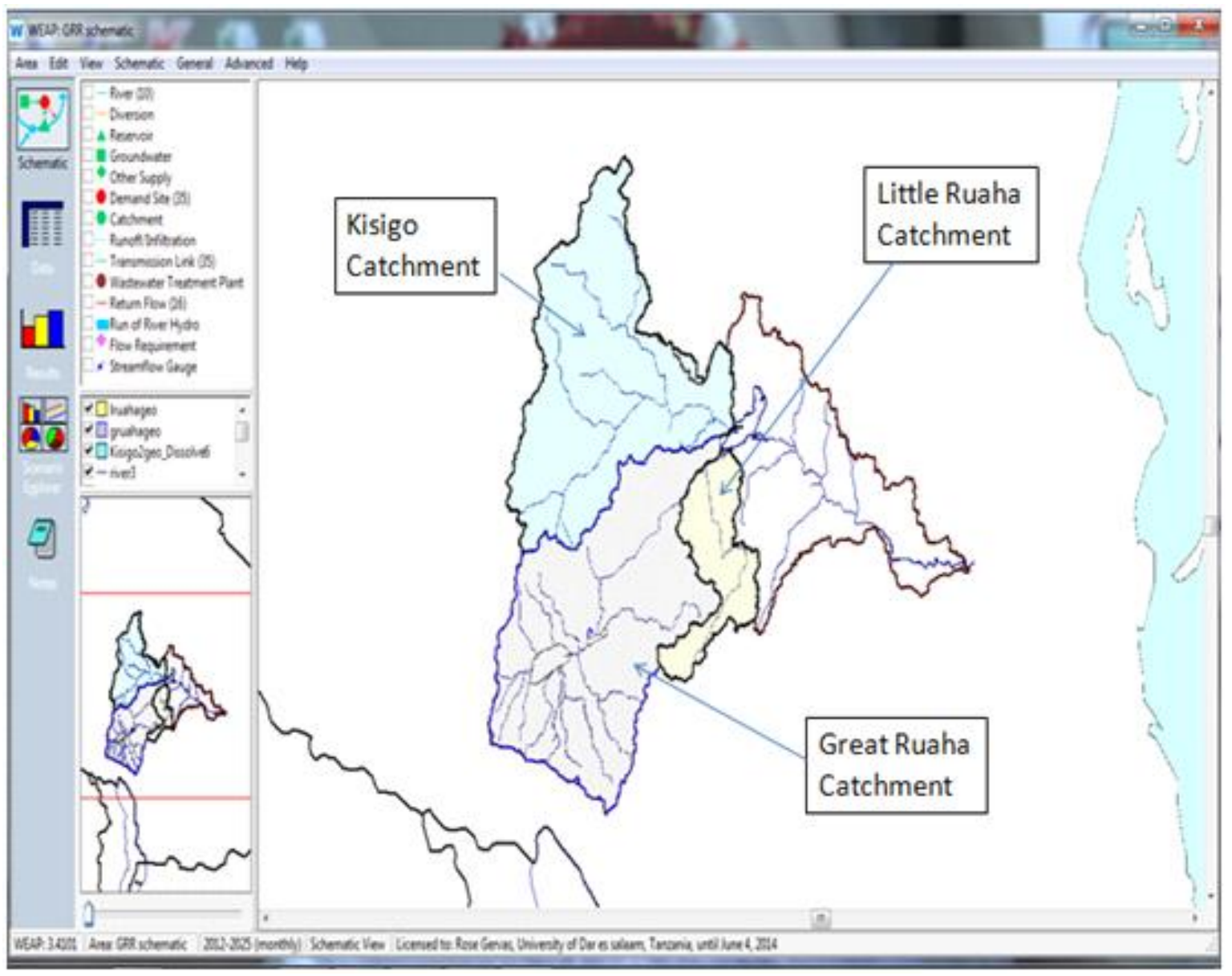

Figure 3: GRR sub-basin with the sub-catchments in WEAP model

\section{Time settings}

The time setting includes defining the current account year and the last year of scenarios and the desired analysis. Then
WEAP runs the simulation on monthly basis for the current to the last year of accounts. The current account is usually the most recent year where reliable and complete data are available, and it forms 
the basis for future demands and scenarios projection. The current account and last year of scenarios chosen for this study was 2012 and 2025 respectively. The period of analysis started with the current account year (2012) and went to the last year of scenarios (2025). A continuous monthly analysis was performed on each year specified for the period of analysis. The study period was chosen because most of the Tanzania development plans are aiming at 2025 .

\section{Schematic setup}

The model setup was done by defining the supply and demand features of the resource system and the system was configured. The demand sites that were modelled by WEAP were indicated by numbers showing water allocation priorities (Figure 4).

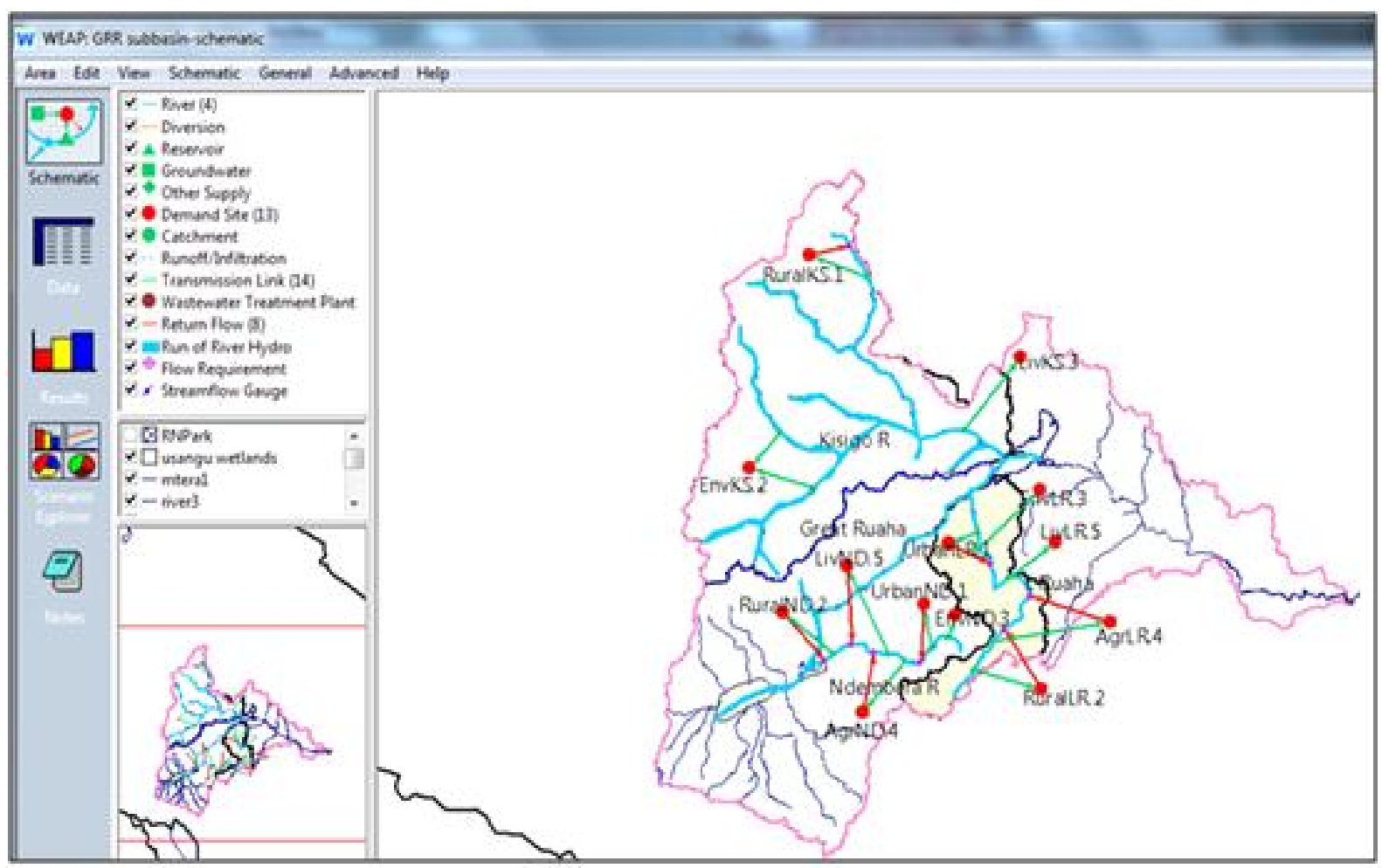

Figure 4: WEAP schematic for GRR sub-basin with demand sites' priorities

\section{Linking demand and supply}

In WEAP, demands and supply are linked by using transmission links. Transmission links were used to convey water from river supplies to demand sites with an allowance for losses, physical capacity and other constraints on water conveyance. This included water supply for irrigation in catchments with irrigation. The links can also be used in case of wastewater and treatment plants. The assumption was that rivers or their tributaries as the only water source in the catchment used to satisfy the demand sites determined in Gervas (2013). No any other supply source was considered in this study due to limited time and resources.

\section{Water allocation priorities}

The water allocation in WEAP was done on the basis of the water demand priorities defined and set for each of the demand site. For each site in GRR sub-basin the priority for withdrawal was established (Table 1) based on the Water Policy, 2002 and Water Resources Management Act of 
Tanzania, 2009. The sites with the highest priorities start with number 1 in order and get water first depending on water available. In this case during water shortage, the high priority site demands are met first before other demands. This implies that when there is plenty of water to satisfy everyone, demand priorities are unnecessary.

\section{Table 1: Water allocation priorities in GRR sub-basin}

\begin{tabular}{|l|c|c|c|c|c|}
\hline Sub catchment & Urban & Rural & EFR & Agriculture & Livestock \\
\hline Little Ruaha & 1 & 2 & 3 & 4 & 5 \\
\hline Great Ruaha & 1 & 2 & 3 & 4 & 5 \\
\hline Kisigo & NA & 1 & 2 & NA & 3 \\
\hline
\end{tabular}

Note: NA means there was no demand in the catchment, hence no priority was set

\section{Developed water allocation scenarios in the GRR sub-basin}

Water allocation assessment requires a scenario approach that considers the future with fundamentally different development and environmental assumptions and policies. Different scenarios that were built in the WEAP model for GRR sub-basin are discussed hereunder. The model was built using observed data and it was assumed that the implementation of the proposed scenarios will take place from the year 2013 .

\section{(a) Reference Scenario (2012-2025)}

The reference scenario was a scenario that uses the actual data to represents the changes that are likely to occur in the future, in the absence of any new policy measure, sometimes called a "business as usual" scenario. This was done to help people learn what likely could occur if current trend continues.

(b) Irrigation expansion scenario (20132025)

Irrigation expansion scenario was run to assess the changes to demand and supply pattern that will take place when the planned expansion of irrigation agriculture takes place. The area under irrigation is to be increased by $4.7 \%$ (based on the Tanzania Irrigation Master Plan, 2025).

(c) EFR implementation scenario (20132025)

Environmental flow requirement scenario was going to answer the question of what will happen if minimum flow requirement is implemented in the rivers of the subbasin (based on the Water Resources Management Act, 2009). Environmental flows are the flows of water in rivers and streams that are necessary to maintain healthy aquatic ecosystems. It is an instream water demand designed to mimic the natural condition in rivers. Accordingly, a low flow characteristic (Q95) estimated from Flow Duration Curve (FDC) was used as the environmental water requirement. The FDC is a plot of discharge against percent of time that a particular discharge was equaled or exceeded. It is the most informative means of displaying the complete range of river discharges from low flows to flood events (Pyrce, 2004). The area under the flow duration curve gives the average monthly flow, the median monthly flow is the $50 \%$ value and the minimum flow to protect the river is the $95 \%$ value (i.e. Q95). Mean monthly values were used to estimate the Q95 using plotting position method. The same values of EFR from historical data were used for the future. 


\section{Calibration of the WEAP model}

The WEAP model was calibrated so as to represent the natural water system in the sub-basin. McCartney et al. (2005) indicated that calibration is done by estimating historical water demand patterns and simulating resultant flow. However, WEAP model does not have an inbuilt automatic calibration routine. This implies that calibration was done manually by modifying the parameters and running the simulation until an optimum outcome is arrived at. The model calibration involves altering demand priorities in Table 1 and changing assumptions about historic demand patterns (McCartney et al., 2005; Arranz and McCartney, 2007; Mulungu and Taipe, 2012) so as to improve or maximize the fit between the simulated and observed flows. Three model performance criteria were used to evaluate model performance: NashSutcliffe efficiency (NSE), coefficient of determination $\left(\mathrm{R}^{2}\right)$ and correlation coefficient (R). Moreover, it was assumed that the hydrology of the catchment is not expected to be significantly affected by climate change within the planning horizon for the study (i.e. 12 years up to
2025). Therefore, the future stream flow variation was mirrored to the 2025 period.

The WEAP model calibration was done using observed flow data from two gauging stations located on the GRR tributaries (Little Ruaha River at 1KA31 and Ndembera River at 1KA15). The data for these stations were processed and it involved filling of the missing values and identification of outliers. However, outliers were not identified. Filling of the missing values was done by using correlation method. This method was selected among other methods because the method is simple to use compared to rainfall-runoff models and it performs better at monthly time scale. From the data records 19562009 for the flow stations, based on data quality checks (i.e. no or very little data gaps) and water demand data availability, model calibration was done from 2002 to 2007 and from 1992 to 1996 for Ndembera (1KA15) and Little Ruaha (1KA 31), respectively. The seasonal flow variation for these two stations is presented in Figure 5, which showed higher flow contribution for 1KA31 than 1KA15 in the GRR with the peak flows in April and March, respectively.

\section{Seasonal flow variation 1956-2009}

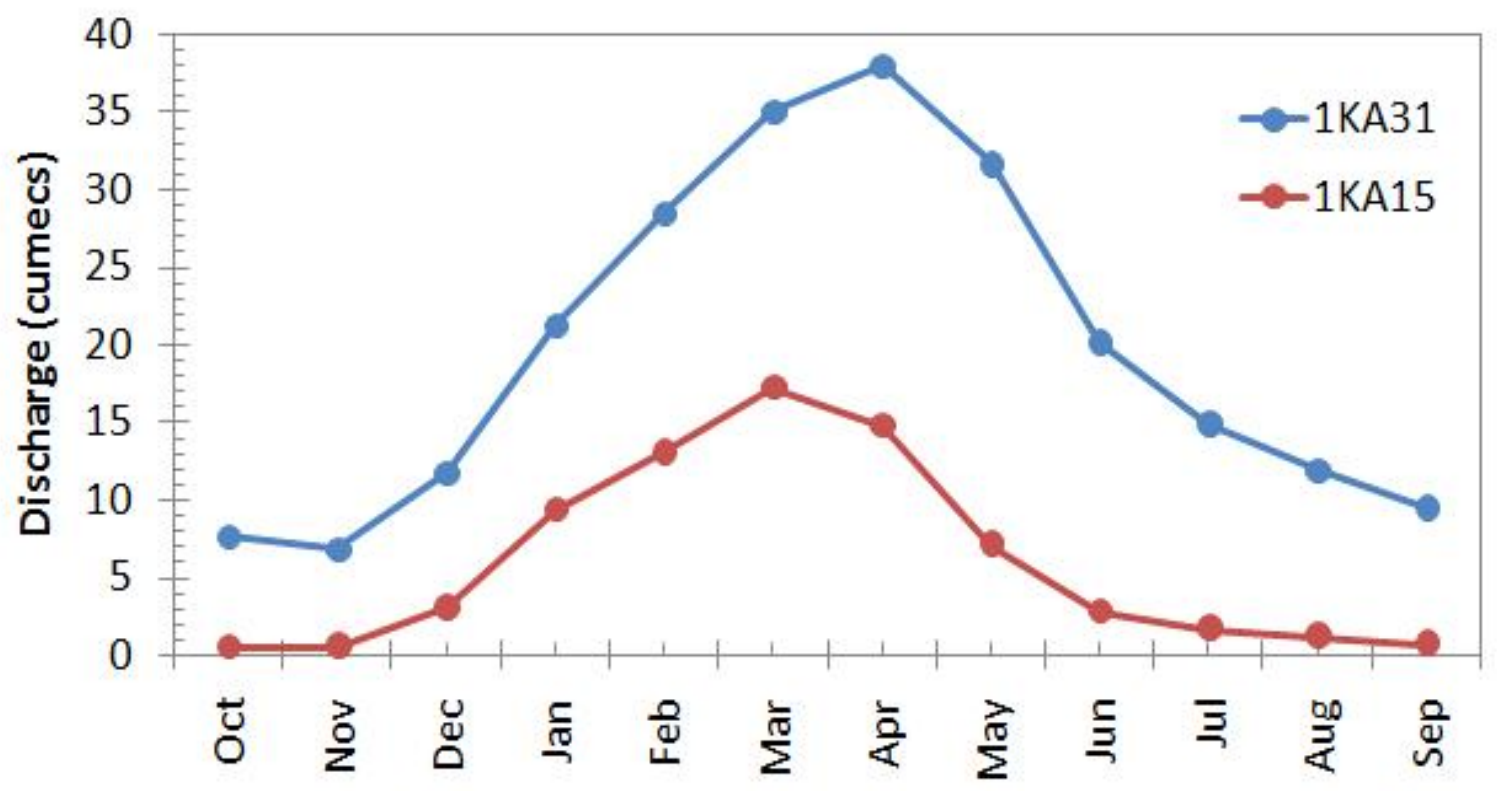

Figure 5: Seasonal flow variation at 1KA31 and 1KA15 
After WEAP calibration, assessment of water allocation involved scenario analysis of demands against supply so as to understand the magnitude of water shortage. The above developed scenarios were implemented in WEAP and analyzed in each sub-catchment of the GRR subbasin.

\section{RESULTS AND DISCUSSION}

\section{Assessment of Water Allocation}

\section{WEAP model calibration}

During model calibration, it was revealed that changing the demand priorities for urban and rural water uses had no effect on the NSE and $\mathrm{R}^{2}$ if there is only one supply source. This may be due to the fact that the high demand sectors such as agriculture were not altered. Accordingly, the model calibration was done by estimating historical water demand patterns without changing assumptions about historic demand patterns. Figure 6 and 7 shows the simulated streamflows related to the observed streamflows for the gauging stations. The statistical model efficiency criteria resulted into NSE, $\mathrm{R}^{2}$ and $\mathrm{R}$ of 0.8 , 0.89 and 0.94 in Ndembera (Figure 6) and NSE, $\mathrm{R}^{2}$ and $\mathrm{R}$ of $0.98,0.84$ and 0.9 in Little Ruaha (Figure 7). These results indicated good model fit and then the model was used for water allocation and scenarios evaluation.

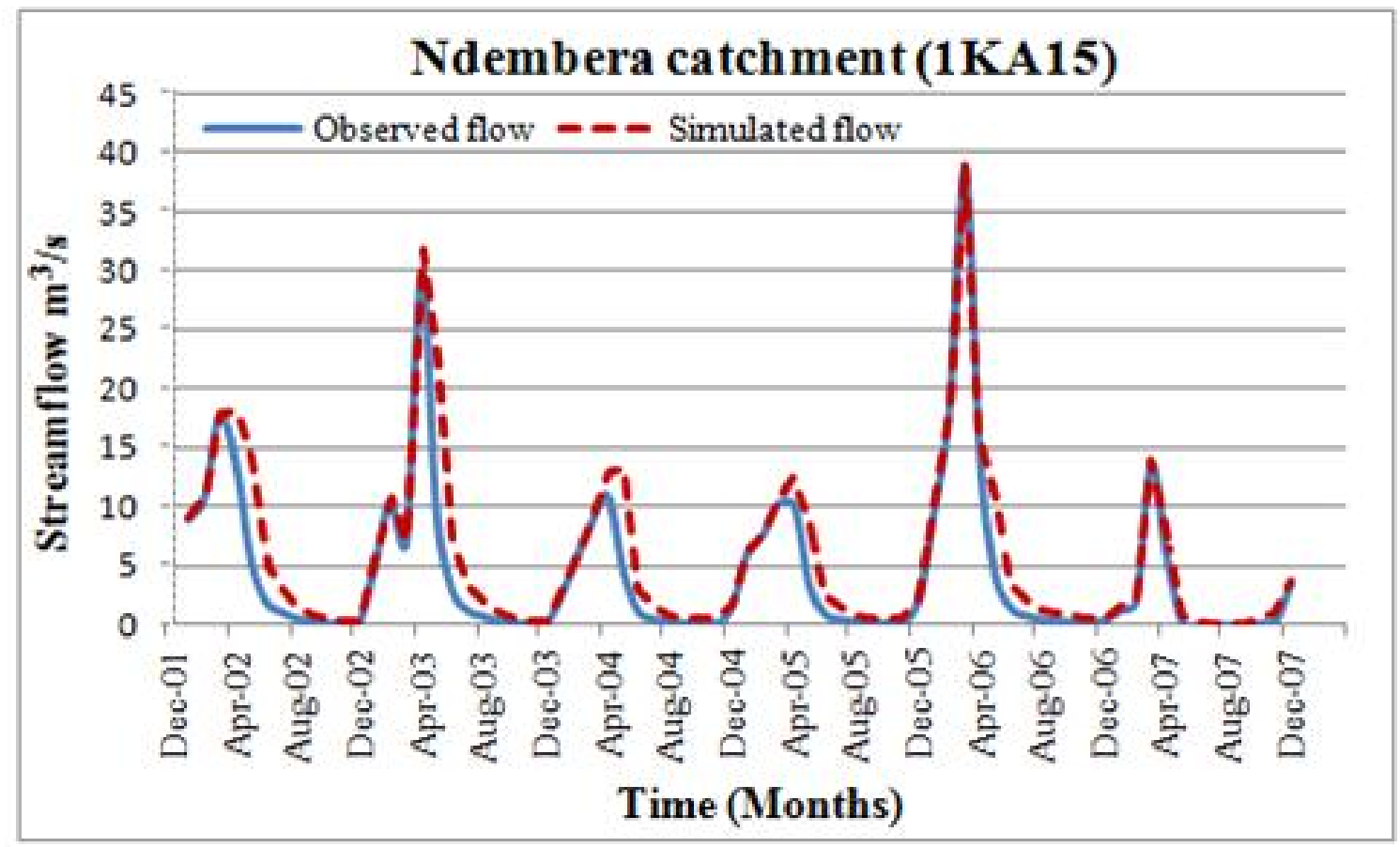

Figure 6: Observed and simulated flow for $1 \mathrm{KA15}\left(\mathrm{NSE}=0.8, \mathrm{R}^{2}=0.89\right)$ 


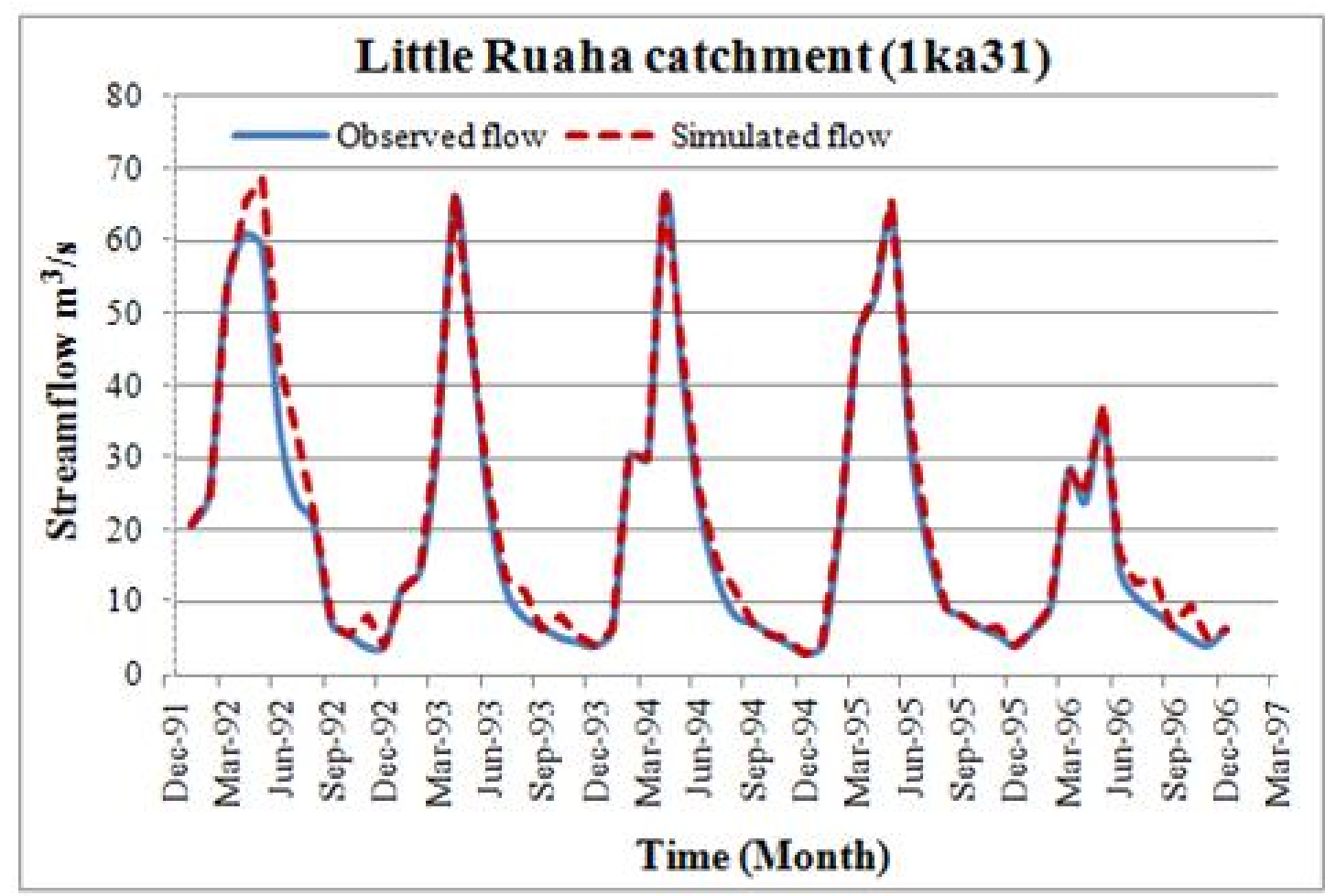

Figure 7: Observed and simulated flow for $1 \mathrm{KA31}\left(\mathrm{NSE}=0.98, \mathrm{R}^{2}=0.84\right)$

\section{Water Allocation in GRR Sub-basin}

\section{Little Ruaha Catchment}

The below are the results for Little Ruaha River catchment (Figure $1 \& 3$ ):

(a) Current unmet demand

The analysis using WEAP model showed that from June-November water supply is insufficient to meet the demands for water in the GRR sub-basin. The high unmet demands are in August-October, which was mostly affected by water demand for agriculture and environment. The reason for high unmet demands is that agriculture was assigned a priority of 5 after environment, livestock, rural and urban water users. The shortages in the agriculture are due to high amount of water required for environment $\left(4^{\text {th }}\right.$ priority) which had to be satisfied before agriculture $\left(5^{\text {th }}\right.$ priority). The total unmet demand in the year 2012 is $104 \mathrm{Mm}^{3}$ of which $94.43 \mathrm{Mm}^{3}(88 \%)$ is experienced on agriculture, $12.83 \mathrm{Mm}^{3}(12 \%)$ on environment and $0.1 \mathrm{Mm}^{3}(0.09 \%)$ on livestock (Figure 8). 


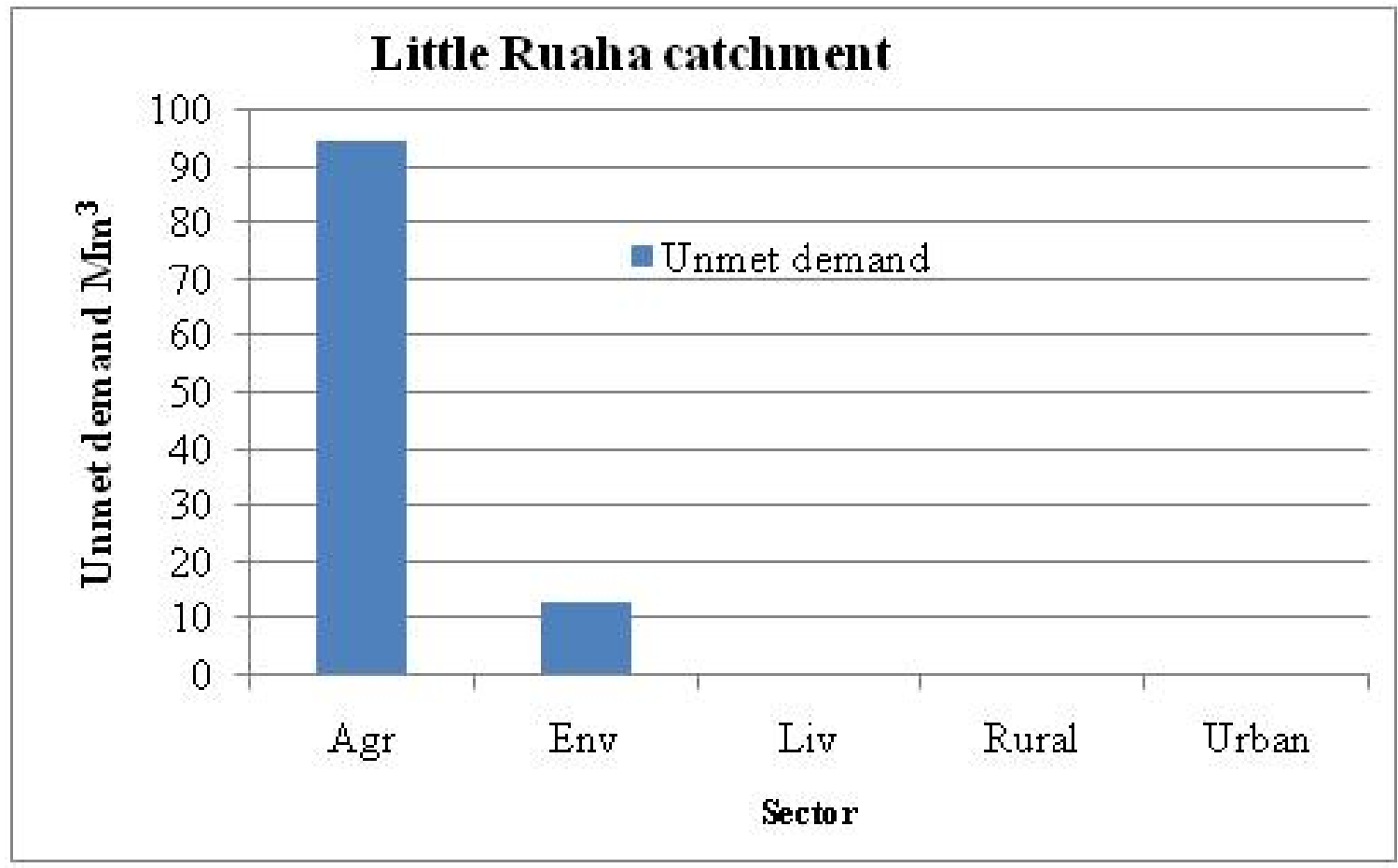

Figure 8: Unmet demand for the year 2012

(Note: Agr - agriculture, Env - environment, Liv - livestock)

(b) Irrigation expansion scenario

Irrigation expansion (IE) scenario was done to determine the impacts of increasing the irrigable land from 6,000 to 11,562 ha on water demand and supply. Annual average water demand for this scenario increased from $760 \mathrm{Mm}^{3}$ in reference scenario to $771.5 \mathrm{Mm}^{3}(1.5 \%$ increase) in irrigation expansion scenario. The annual average unmet water demand increased from $179.5 \mathrm{Mm}^{3}$ in reference scenario to $193.5 \mathrm{Mm}^{3}$ in irrigation expansion scenario (Figure 9). Monthly average unmet water demand increased from 15 to $16.1 \mathrm{Mm}^{3}$ (Figure 9). The results identified that water shortage increased by $7.8 \%$ (annual mean) and $7.35 \%$ on monthly, which impact negatively other water users in the subcatchment which can lead to low economic development.

(c) EFR implementation scenario

Implementation of EFR increases shortages in the catchment as the amount of water available for agriculture, livestock and non-domestic abstractions is reduced. A water allocation priority of 3 was given to EFR after domestic (urban and rural). The annual average water demand for this scenario increased from $760 \mathrm{Mm}^{3}$ in reference scenario to $766 \mathrm{Mm}^{3}$ in EFR scenario. The annual average unmet water demand increased from $30.1 \mathrm{Mm}^{3}$ in reference scenario to $33.2 \mathrm{Mm}^{3}$ in EFR scenario (Figure 10). The results indicated that water shortage (annual mean) will increase by $10.3 \%$, which will impact negatively on other water users in the subcatchment and can lead to low economic development.

(d) Irrigation expansion and EFR implementation scenarios

The mean annual water demand for the combined irrigation expansion and EFR implementation scenario increases from $760 \mathrm{Mm}^{3}$ in reference to $771.5 \mathrm{Mm}^{3}$ (Figure 11). The annual average shortages will increase to $227.6 \mathrm{Mm}^{3}$ compared to $179.5 \mathrm{Mm}^{3}$ for reference, $193.5 \mathrm{Mm}^{3}$ for irrigation expansion and $33.2 \mathrm{Mm}^{3}$ for EFR implementation. The increase is $27 \%$ 
above reference scenario. This indicated that when combined irrigation expansion and EFR implementation are considered, more water shortage will occur and thus increased impact on other water users in the sub-catchment leading to more low economic development.
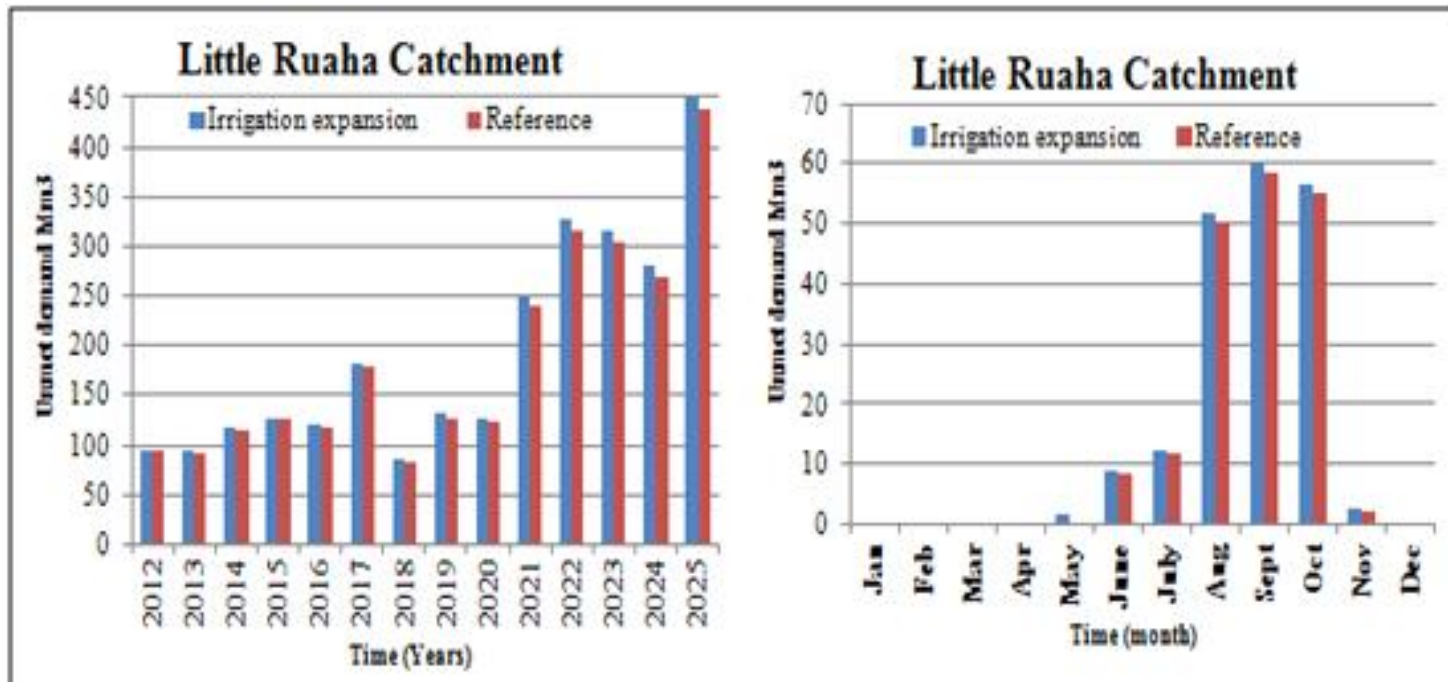

Figure 9: Annually and seasonally unmet water demand for reference and IE scenarios

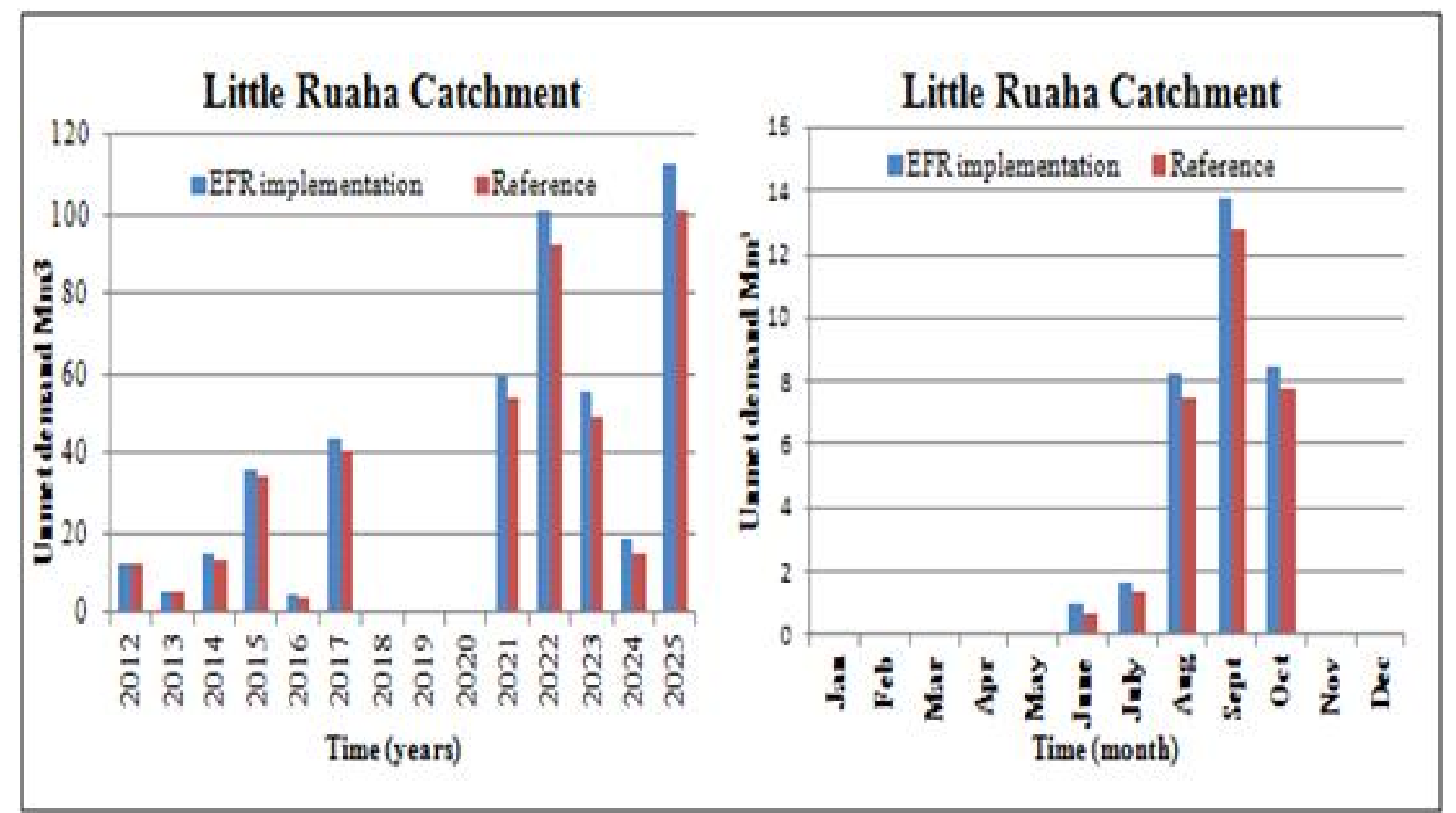

Figure 10: Annually and seasonally unmet water demand for EFR scenario 


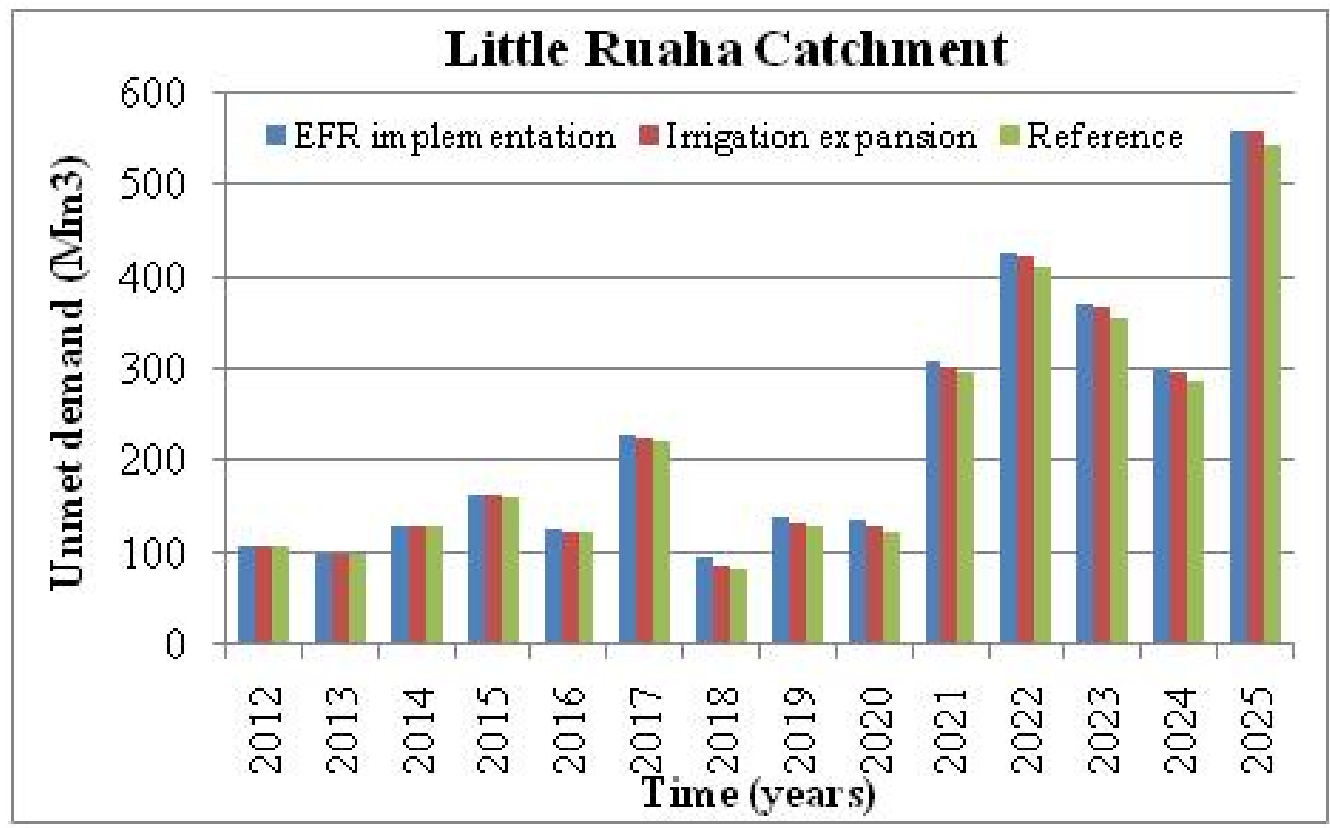

Figure 11: Annual average unmet water demand for all the scenarios

\section{Ndembera catchment}

For Ndembera River catchment, results of the three scenarios are shown below (Figures 1, 3 and 12):

\section{(a) Irrigation expansion scenario}

Irrigation expansion scenario was done to determine the impacts of increasing the irrigable land from 5,004 to 8,758 ha on water demand. Annual average water demand for this scenario increased from $374.1 \mathrm{Mm}^{3}$ in reference scenario to 380.1
$\mathrm{Mm}^{3} \quad(1.6 \%$ increase $)$ in irrigation expansion scenario. The annual average unmet water demand (Figure 12) increased from $238.3 \mathrm{Mm}^{3}$ in reference scenario to $243.9 \mathrm{Mm}^{3}$ in irrigation expansion scenario (2.4\% increases). Monthly average unmet water demand increased from 15 to $16.1 \mathrm{Mm}^{3}$ (Figure 13). These increased water shortages of $2.4 \%$ annually and $7.3 \%$ monthly will impact negatively on the other water users in the sub-catchment which can lead to low economic development in Ndembera. 


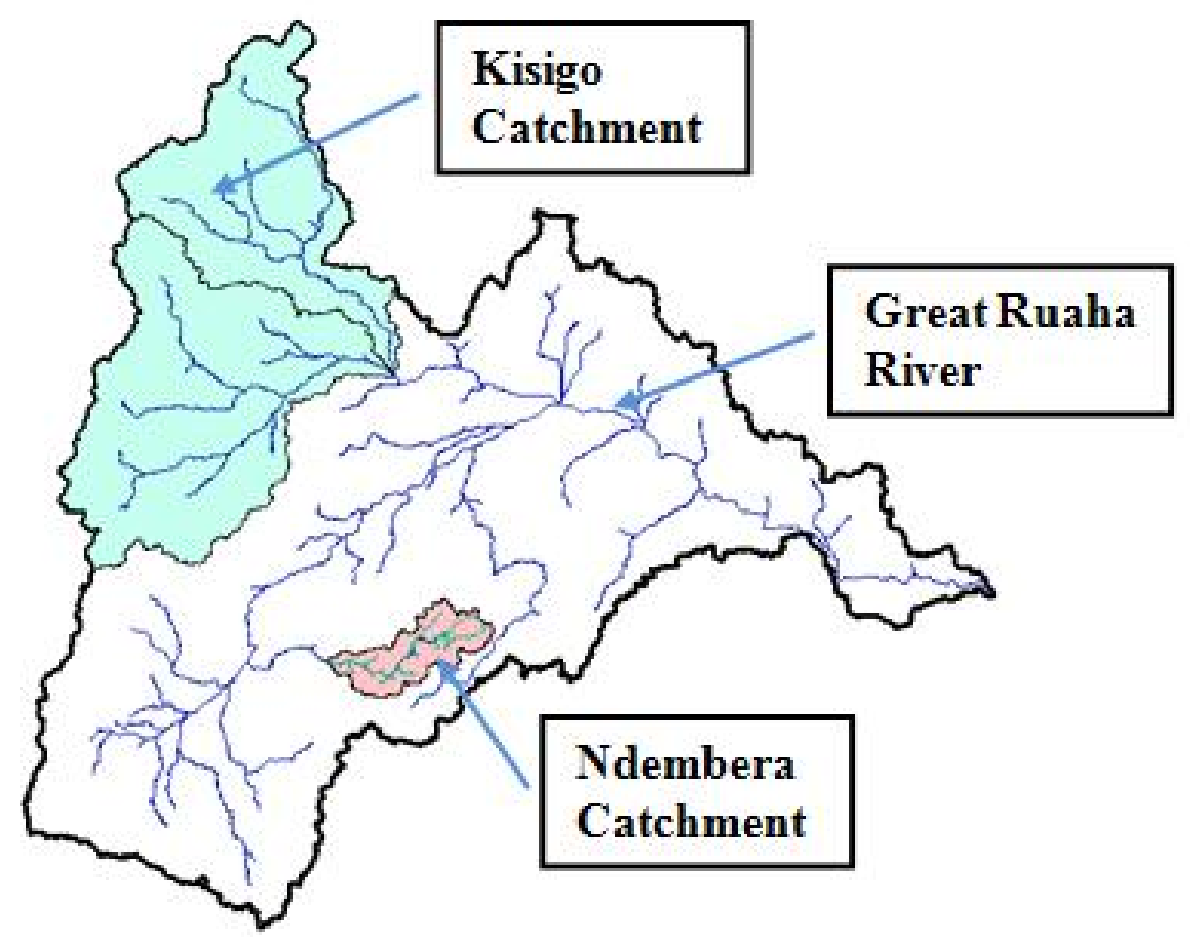

Figure 12: Location of Ndembera and Kisigo catchments in GRR sub-basin
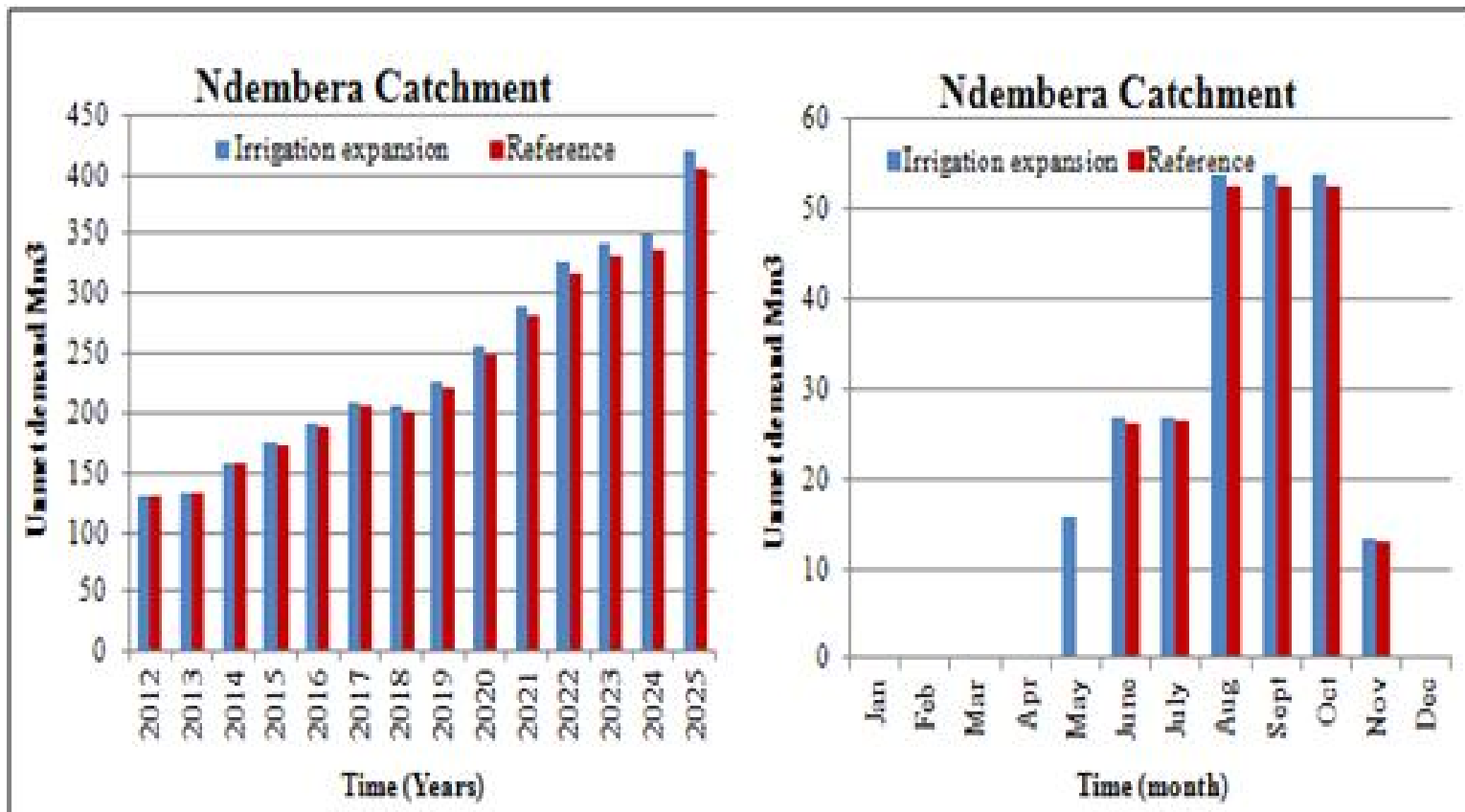

Figure 13: Annually and seasonally unmet water demand for reference and IE scenarios

(b) EFR implementation scenario

The annual average water demand for this scenario increased from $374.1 \mathrm{Mm}^{3}$ in reference scenario to $376.9 \mathrm{Mm}^{3}$ in EFR scenario. The annual average unmet water demand will increase from $77.4 \mathrm{Mm}^{3}$ in reference scenario to $79.9 \mathrm{Mm}^{3}$ in EFR scenario (Figure 14). The $3.2 \%$ increase annually could impact the downstream uses and demands with low priority. 
(c) Irrigation expansion and EFR implementation scenarios

The mean annual water demand for the combined irrigation expansion and EFR implementation scenario increases from $374.1 \mathrm{Mm}^{3}$ in reference to $380.1 \mathrm{Mm}^{3}$.
The annual average shortages will increase to $322.2 \mathrm{Mm}^{3}$ compared to $316.6 \mathrm{Mm}^{3}$ for reference, $243.9 \mathrm{Mm}^{3}$ for irrigation expansion and $79.9 \mathrm{Mm}^{3}$ for EFR implementation. This presents an increase of $1.77 \%$ above reference scenario.

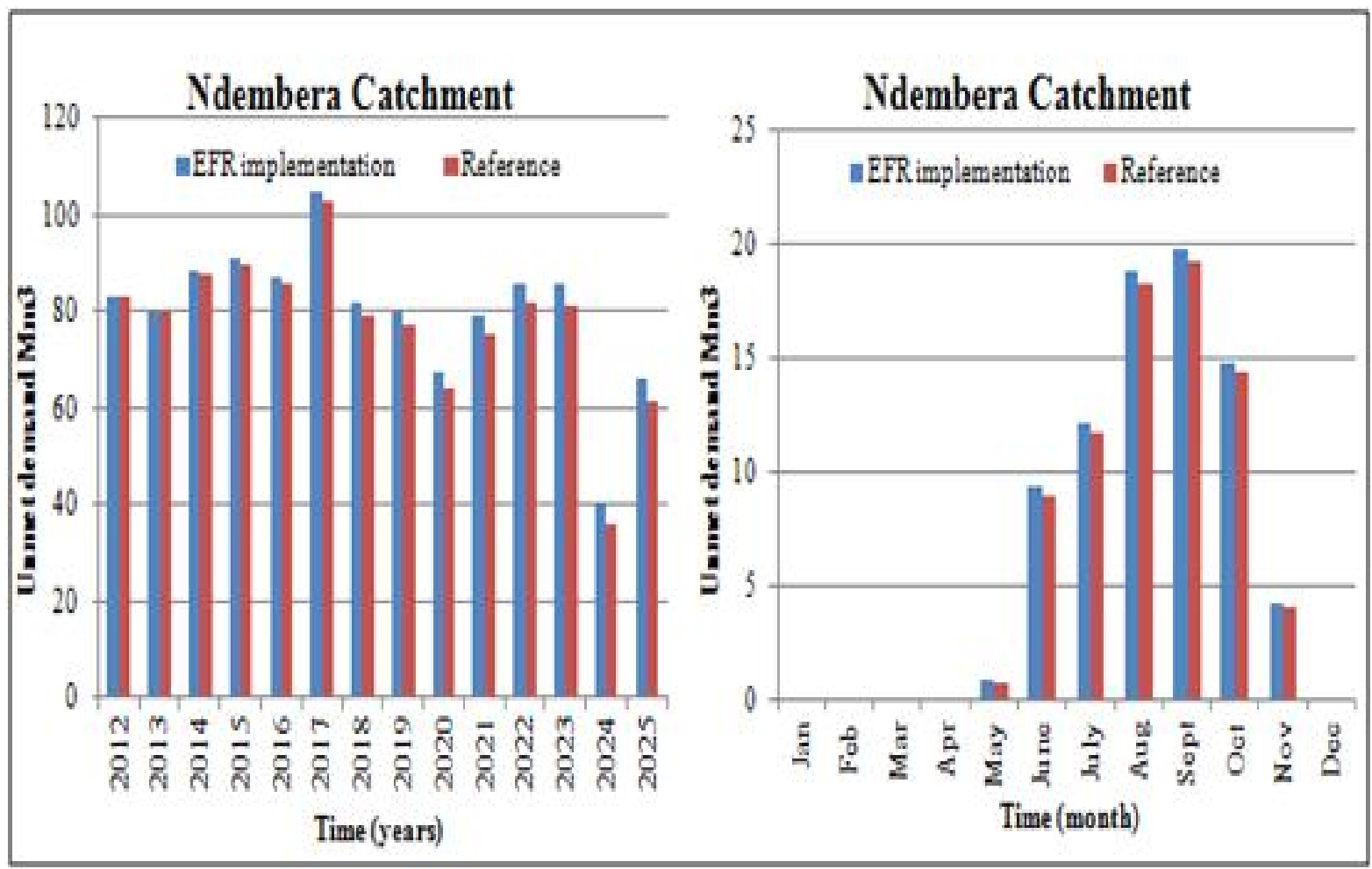

Figure 14: Annually and seasonally unmet water demand for reference and EFR scenario for Ndembera catchment

\section{Kisigo catchment}

The below are the results for Kisigo River catchment (Figure 1, 3 and 12):

(a) EFR implementation scenario

Kisigo sub-catchment is largely covered with the Ruaha National Park and currently there is no agricultural activities taking place. Kisigo River is seasonal but it has very high runoff during the wet season, which contributes significantly to the flow of the Great Ruaha River. The annual average water demand for this scenario increased from $64.42 \mathrm{Mm}^{3}$ in reference scenario to $66.01 \mathrm{Mm}^{3}$ in EFR scenario. The annual average unmet water demand increased from $42.79 \mathrm{Mm}^{3}$ in reference scenario to $44.12 \mathrm{Mm}^{3}$ in EFR scenario (Figure 15). This is an increase of $3.1 \%$ of unmet demand annually. The results show that the unmet water demand will decrease or increase in some years from the reference to EFR implementation scenario. 


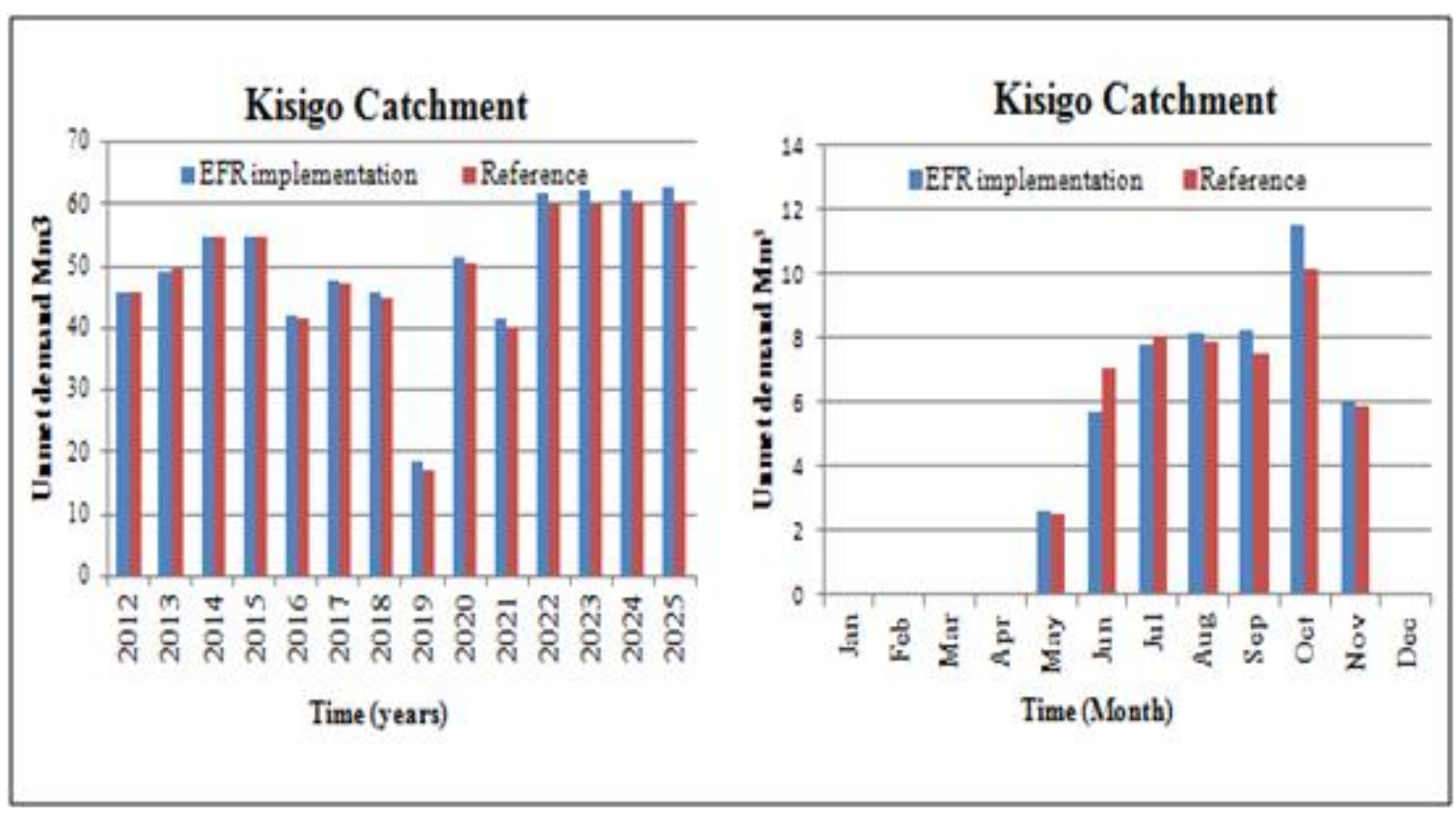

\section{Figure 15: Annually and seasonally unmet water demand for EFR implementation scenario for Kisigo catchment}

\section{DISCUSSION}

Comparing the above three catchments, in relation to annual irrigation water demands, the Little Ruaha catchment is expected to have the highest increase $(10.3 \%)$ in unmet demand unlike Ndembera with $2.4 \%$ increase by 2025 . The large increase for Little Ruaha catchment is tied to its large catchment area of about $6,210 \mathrm{~km}^{2}$ with the current and potential total irrigable area of about 25,300 ha despite the likely more river flows compared to Ndembera catchment with only about $3,190 \mathrm{~km}^{2}$ catchment area and 12,627 ha of current and future irrigation area. The entire Usangu plain has the largest potential irrigation agricultural area of about 208,000 ha in the GRR basin. The same applies to EFR where there is increase of $10.3 \%$ against $3.2 \%$ and $3.1 \%$ for Little Ruaha, Ndembera and Kisigo catchments, respectively. Despite its catchment size and hence more water supply for the Little Ruaha River, irrigation needs more water thus leading to unmet water demand. It is worth to note that the surface flow contributions of the Great Ruaha, Little
Ruaha and Kisigo rivers to the total inflow to the Mtera reservoir are estimated as $56 \%, 18 \%$ and 26\%, respectively (Kashaigili et al., 2005). Also, Mbungu and Kashaigili (2017) revealed reduction and changes of streamflows with time and therefore more water shortages are expected on the planned water development and related ecosystems in the Little Ruaha catchment. Moreover, Munkyala (2017) indicated that irrigation is the big water user in the Ndembera catchment, which accounts for about $77 \%$ of the all water demands in the catchment. Several scenarios were proposed and analyzed using the Nile Basin Decision Support System to address the issue of water shortages in the catchment. This implies that although there are plans for developing irrigation in the GRR basin, this has to be done cautiously in order to benefit from it and not bringing more challenges or loss of investment. Detailed prior analysis of the crops and their irrigation water requirement, and in consideration of other demands in the basin and available water sources need to be done. In this case, the WEAP model can further be used in consideration of the 
varied irrigation demands and water supplies including groundwater.

\section{CONCLUSIONS}

The current surface water demands and supply were linked using WEAP model to determine the future water allocation based on the set scenarios. In this study water was allocated based on priorities set in the Water Resources Management Act, 2009 with priorities of $1,2,3,4$ and 5 in domestic (urban and rural), environment, agriculture and livestock respectively. The WEAP modelling of the GRR along with the input data has several limitations and a number of assumptions were made. The GRR sub-basin was sub-divided into three catchments and the hydrological and water demand data were lumped accordingly. The individual water demands belonging to the same sector were combined, given the same water allocation priority and the surface water generated in the catchment and upstream was supplied for them. Groundwater was assumed to have no effect on water demand and streamflow. All these assumptions and limitations must be taken into consideration when interpreting the results. The current total demands before implementation of the scenarios are 623.6, 388.17 and 110.23 $\mathrm{Mm}^{3}$ for Little Ruaha, Ndembera and Kisigo of which irrigation, environment, domestic, non-domestic and livestock constitutes $49 \%, 27 \%, 15 \%, 5 \%$ and $3 \%$, respectively.

The future water demands increased for all the simulated scenarios producing greater shortages. With comparison to reference scenario, the planned irrigated agriculture expansion will increase shortages in the Little Ruaha and Ndembera catchments by $149 \%$ and $126 \%$ respectively. There is no current and future plan for agriculture in Kisigo as the largest part of it falls in the Ruaha National Park. The EFR implementation scenario will also increase shortages in the Little Ruaha, Ndembera and Kisigo catchments by $147 \%, 121 \%$ and $13 \%$, respectively. This implies that in view of the EFR considerations, which are now a pre-requisite all over the world, practicing these regulations implies that there would be water shortages in the demand sectors compared to the current practice which does not put EFR under considerations.

\section{RECOMMENDATIONS}

The study recommends improving the surface water allocation results in GRR sub-basin and indeed taking advantage of other powerful capabilities of WEAP model as follows:

- Construction of reservoirs to store and release water, supply management techniques for instance, considering other sources of water (especially in agriculture) and water demand management measures (e.g. use of irrigation efficiency methods such as drip or sprinkler) can eliminate the obtained water shortages in the catchments.

- Incorporation of other features and supply sources like groundwater, water quality and cost benefit analysis modules in order to get a complete picture of the integrated water resources management of the GRR sub-basin

- Impact of climate change on future streamflow may also be used as one of the scenarios in assessing future water allocation

\section{Acknowledgement}

The authors acknowledge financial support extended to the first author by iWASH Glows Tanzania for the study scholarship for the Master of Integrated Water Resources Management at the University of Dar es Salaam, upon which this paper is based. 


\section{REFERENCES}

Arranz R. and McCartney M. (2007). Application of the Water Evaluation and Planning (WEAP) model to assess future water demands and resources in the Olifants catchment, South Africa, Colombo, Sri Lanka. IWMI working paper 116: International Water Management Institute.

Chanzi G. (2017). Assessment of Water Availability and Uses at Kilombero Basin Using SWAT and WEAP Models. MSc Dissertation in Water Resources Engineering, Department of Water Resources Engineering, University of Dar es Salaam, Tanzania.

DHI Water and Environment (2006). MIKE Basin Simulation Model: A Versatile Decision Support Tool for Integrated Water Resources Management and Planning Horshelm, Denmark.

http://www.dhisoftware.com/mikebasin lindex.html. Retrieved on 29th July 2013.

Gervas R. (2013). Analysis of water resources allocation in the Great Ruaha River sub-basin, Tanzania. Master of Integrated Water Resources Management, Department of Water Resources Engineering, University of Dar es Salaam, Tanzania.

Kadigi R.M.J., Kashaigili J.J. and Mdoe N.S. (2004). The economics of irrigated paddy in Usangu Basin in Tanzania: Water utilization, productivity, income and livelihood implications. Physics and Chemistry of the Earth, 29(15-18): 1091-1100.

Kashaigili J.J., Kadigi R.M.J., Lankford B.A., Mahoo H.F. and Mashauri D.A. (2005). Environmental flows allocation in river basins, Exploring allocation challenges and options in the GRR catchment in Tanzania, Physics and Chemistry of the Earth, Parts $\mathrm{A} / \mathrm{B} / \mathrm{C}$, 30(11-16): 689-697.

Kashaigili J.J., Mc Cartney M.P., Mahoo H.F, Lankford B.A., Mbilinyi B.P.,
Yawson D.K. and Tumbo S.D. (2006). Use of a hydrological model for environmental management of the Usangu Wetlands, Tanzania. Research Report 104, Colombo Sri Lanka: International Water Management Institute, 48 p. Doi: http://dx.doi.org/10.3910/2009.104.

Kishiwa P., Nobert J., Kongo V. and Ndomba P. (2018). Assessment of impacts of climate change on surface water availability using coupled SWAT and WEAP models: Case of Upper Pangani River Basin, Tanzania. Proceedings of the International Association of Hydrological Sciences 378: 23-27.

Lankford B. (2002). Irrigation, livelihoods and river basins, LADDER Working Paper No. 14. ODG, Norwich, UK.

Lankford B.A., van Koppen B., Franks T. and Mahoo H.F. (2004). Entrenched views or insufficient science? Contested causes and solutions of water allocation; insights from the Great Ruaha River Basin, Tanzania. Agricultural Water Management 69(2): 135-153.

McCartney M.P., Yawson D.K. and Huber-Lee A. (2005). Simulating water resources development in the Olifants catchment, South Africa. IWMI Theme 1, Working Paper (Draft). International Water Management Institute (IWMI).

Mbungu W.B. and Kashaigili J.J. (2017). Assessing the hydrology of a datascarce tropical watershed using the Soil and Water Assessment Tool: Case of the Little Ruaha River Watershed in Iringa, Tanzania. Open Journal of Modern Hydrology, 7: 65-89.

Mulungu D.M.M. and Taipe C.L.R. (2012). Chapter 2: Water evaluation and planning in the Wami River Basin: Application of the WEAP model in Bioenergy and Food Security, the BEFS Analysis for Tanzania. Edited by E. Beall, FAO 54, ISSN 2226 - 6062.

Munkyala D. (2017). Assessment of surface water resources potential and its 
allocation in Ndembera catchment, Rufiji basin. Master of Integrated Water Resources Management, Department of Water Resources Engineering, University of Dar es Salaam, Tanzania.

Mwakalila S. (2005). Water Resources Management Guidelines in Ruaha Basin, Tanzania, Conference paper h041160, International Water Management Institute, 18p..

Perera B.J.C, James B. and Kularathna M.D.U. (2005). Computer software tool REALM for sustainable water allocation and management, Journal of Environmental Management, 77: 291300.

Pyrce R. (2004). Hydrological low flow indices and their uses. WSC Report No. 04-2004, Watershed Science Centre
(WSC), Trent University, Peterborough, Canada, 50p.

Sieber J., Huber-Lee A. and Raskin P. (2002). WEAP: Water Evaluation and Planning System User Guide (for WEAP 21), Stockholm Environmental Institute-Boston, and Tellus Institute.

Sieber J., Yates D., Huber Lee A. and Purkey D. (2005). WEAP: a demand priority and preference driven water planning model: Part 1, model characteristics. Water International, 30(4): 487-500.

SMUWC (2001). Sustainable Management of the Usangu Wetland and its Catchment. Supporting Report 12: Groundwater. A report to the Ministry of Water and Livestock. 